Article

\title{
Availability of Biomass Residues for Co-Firing in Peninsular Malaysia: Implications for Cost and GHG Emissions in the Electricity Sector
}

\author{
W. Michael Griffin ${ }^{1, *}$, Jeremy Michalek ${ }^{2}$, H. Scott Matthews ${ }^{3}$ and Mohd Nor Azman Hassan ${ }^{4}$ \\ 1 Department of Engineering and Public Policy and the Tepper School of Business, \\ Carnegie Mellon University, 5000 Forbes Avenue, Pittsburgh, PA 15203, USA \\ 2 Department of Mechanical Engineering and the Department of Engineering and Public Policy, Carnegie \\ Mellon University, 5000 Forbes Avenue, Pittsburgh, PA 15203, USA; E-Mail: jmichalek@cmu.edu \\ 3 Department of Civil and Environmental Engineering and the Department of Engineering and Public \\ Policy, Carnegie Mellon University, 5000 Forbes Avenue, Pittsburgh, PA 15203, USA; \\ E-Mail: hsm@cmu.edu
}

4 Department of Engineering and Public Policy, Carnegie Mellon University, 5000 Forbes Avenue, Pittsburgh, PA 15203, USA

* Author to whom correspondence should be addressed; E-Mail: wmichaelgriffin@cmu.edu; Tel.: +1-412-268-2299; Fax: +1-412-268-7357.

Received: 14 December 2013; in revised form: 14 January 2014 / Accepted: 8 February 2014 / Published: 18 February 2014

\begin{abstract}
Fossil fuels comprise 93\% of Malaysia's electricity generation and account for $36 \%$ of the country's 2010 Greenhouse Gas (GHG) emissions. The government has targeted the installation of $330 \mathrm{MW}$ of biomass electricity generation capacity by 2015 to avoid 1.3 $\mathrm{Mt}$ of $\mathrm{CO}_{2}$ emissions annually and offset some emissions due to increased coal use. One biomass option is to co-fire with coal, which can result in reduced GHG emissions, coal use, and costs of electricity. A linear optimization cost model was developed using seven types of biomass residues for Peninsular Malaysia. Results suggest that about $12 \mathrm{Mt} /$ year of residues are available annually, of which oil-palm residues contribute $77 \%$, and rice and logging residues comprise $17 \%$. While minimizing the cost of biomass and biomass residue transport, co-firing at four existing coal plants in Peninsular Malaysia could meet the 330 MW biomass electricity target and reduce costs by about \$24 million per year compared to coal use alone and reduces GHG emissions by $1.9 \mathrm{Mt}$ of $\mathrm{CO}_{2}$. Maximizing emissions reduction for biomass co-firing results in $17 \mathrm{Mt}$ of $\mathrm{CO}_{2}$ reductions at a cost of $\$ 23 / \mathrm{t}$ of $\mathrm{CO}_{2}$ reduced.
\end{abstract}


Keywords: biomass; co-firing; coal generation; cost optimization; greenhouse gas emissions

\section{Introduction}

The electricity generation sector was Malaysia's second largest energy consumer in 2009, representing approximately $350 \mathrm{PJ}$ or $21 \%$ of Malaysia's total energy consumption [1]. Electricity production is fossil fuel dependent, with 57 million MWh being generated from natural gas and 37 million MWh from coal [2]. Coal use is expected to increase four-fold by 2030, while natural gas will decrease by almost half [3]. Because of its dependence on fossil fuels, particularly coal, electricity generation results in $36 \%$ of the country's total GHG emissions based on average world direct GHG emissions factors for coal and natural gas [4-7]. In response to anticipated emissions increases from the sector, Malaysia intends to install $975 \mathrm{MW}$ of renewable electricity that will include $330 \mathrm{MW}$ generated from biomass. These actions are expected to reduce GHG emissions by $3.2 \mathrm{Mt}$ of $\mathrm{CO}_{2}$ in 2015 [8]. The biomass component of this initiative is equivalent to producing about 2.0 million $\mathrm{MWh}$ of electricity. Malaysia currently has about $225 \mathrm{MW}$ of direct combustion biomass electricity generation capacity [2], fueled by oil-palm and rice residues, wood chips and sawdust, and municipal solid waste (MSW) [2].

Lim et al. [9] estimated that Malaysia could generate approximately 250 million MWh of electricity annually using biomass [2]. The increased supply of biomass would come mainly from logging and oil-palm residues, with the remainder from rubber, cocoa and coconut residues and rice husks and straw [9,10]. A more recent study by Muis et al. [11] estimated biomass electricity could replace up to $9 \%$ of Malaysian electricity and reduce up to $29 \mathrm{Mt}$ of $\mathrm{CO}_{2}$-eq annually compared to the current generation mix. Although there appears to be ample biomass to meet the Malaysian strategy of increasing biomass generated electricity, neither study accounted for relevant biomass use factors, such as recovery rates, competing uses, and recoverability/accessibility factors. Also, neither study considered biomass co-firing with coal as an alternative to direct biomass firing.

Biomass co-firing has a number of advantages over the direct biomass firing approach. It can be adopted with minimal capital investment, depending on level of co-firing, and achieve higher combustion efficiencies than dedicated biomass power plants [12]. Residues are widely produced as part of the normal agribusiness and its use requires only the development of a collection system to deliver from source to coal plant locations [13]. This system can be developed incrementally and evaluated for efficacy periodically. If so desired, the program can be modified or even stopped with minimal risks in comparison to a stand-alone biomass fired electricity plant. Biomass can reduce GHG emission with minimal investments at the power plant and has the co-benefit of reducing $\mathrm{SO}_{\mathrm{x}}$ and $\mathrm{NO}_{\mathrm{x}}$ emissions from facilities currently co-located near population centers. For an extensive review of the technology and application of biomass co-firing see [14].

Biomass energy is assumed to have net-zero GHG combustion related emissions [15], but positive emissions over the life cycle can arise from harvesting activities and delivering of the biomass to the processing facilities. For example, the expansion of oil-palm plantations in Malaysia has increased in GHG emissions from the agricultural sector. According to Henson, in 2005 oil-palm cultivation (planting and harvesting) and palm-oil production in Malaysia emitted about $13 \mathrm{Mt}$ of GHG emissions 
annually [16]. The main sources of these emissions were attributed to land conversion, methane emissions from palm oil mill effluent treatment via anaerobic digestion, fossil-fuel combustion, and fertilizer use.

In order to evaluate the potential of meeting Malaysia's goal of adding $330 \mathrm{MW}$ of electricity using biomass co-firing with coal, this paper provides estimates of: (i) the amounts and locations of biomass residues in Peninsular Malaysia that can be used for electricity generation; (ii) the amount of biomass residues that can be co-fired with coal, while minimizing cost compared to $100 \%$ coal generation; and (iii) the GHG emissions reductions that can be achieved via biomass coal co-firing. Malaysia is divided into two regions: Peninsular/West and East Malaysia. This study focuses on Peninsular Malaysia, which is more developed than East Malaysia and accounts for $91 \%$ of the country's electricity generation [2].

\section{Experimental Section}

\subsection{Estimation of Residue Amounts}

The residues chosen for the co-firing scenarios include: forestry, agriculture, and the wood-based fraction of municipal solid waste (MSW). Residues from the forestry sector comprise logging leftovers, as well as residues generated at mills (sawdust, slabs, trimmings and edgings) and have been estimated to be around 7.4 Mt annually [17]. Agricultural residues include those generated by the oil-palm industry, rubber plantations, and rice production. Agricultural residues have been estimated to be about $17 \mathrm{Mt}$ [17]. Wood-based MSW, estimated at about $7 \mathrm{Mt}$, was modeled because of its general availability throughout the region having 98 landfill sites in Peninsular Malaysia [18].

Available residues are defined as those residues capable of being collected minus the amount that have current uses. This value was estimated using the residue to product ratio (RPR) of crops/products, the accessibility and recoverability factor and the estimated percentage of residues being used in other sectors/products (see Table 1). These values were obtained from the literature, as noted in the table. The estimated total residues available for each type of biomass were then distributed (by weight) to the specific mills according to mill capacity (for process-based residues) and fields/plantations (for field-based residues) by area. As an example, the 120,000 $\mathrm{t}$ of total rice husks available were assigned to the 230 rice mills according to their processing capacities. Rice mills were found to have capacity between 2 and 1900 t/year with an average of about 520 t/year. See Supplemental Information for a detailed explanation on the estimation of the residues amounts.

Table 1. Residues to product ratio (RPR), accessibility and recoverability factor and fraction used for other purposes of the different biomass types used in this study.

\begin{tabular}{cccc}
\hline Residue type & RPR & $\begin{array}{c}\text { Accessibility and } \\
\text { recoverability factor }\end{array}$ & $\begin{array}{c}\text { Fraction used for } \\
\text { other purposes }\end{array}$ \\
\hline Palm Empty Fruit Bunch (EFB) & $1.3-1.6 \mathrm{t} / \mathrm{ha}[19]$ & $1.0[20]$ & $0.65[2,21,22]$ \\
Palm shell & $1.0 \mathrm{t} / \mathrm{ha}[23]$ & $1.0[20]$ & $0.6[2,21]$ \\
Palm fiber & $1.6 \mathrm{t} / \mathrm{ha}[19]$ & $1.0[20]$ & $0.6[2,21]$ \\
\hline
\end{tabular}


Table 1. Cont.

\begin{tabular}{cccc}
\hline Residue type & RPR & $\begin{array}{c}\text { Accessibility and } \\
\text { recoverability factor }\end{array}$ & $\begin{array}{c}\text { Fraction used for } \\
\text { other purposes }\end{array}$ \\
\hline Rice husk & $0.78 \mathrm{t} / \mathrm{ha}[24]$ & $1.0[25,26]$ & $0.55[24,27]$ \\
Wood and paper-based MSW & $0.22 \mathrm{t} / \mathrm{t}$ MSW [28] & $0.67[29]$ & $0.17[30]$ \\
Sawmills & $0.25 \mathrm{t} / \mathrm{t}$ of input logs [17,31] & $1.0[32]$ & $0.81[9,33]$ \\
Plywood mills & $0.47 \mathrm{t} / \mathrm{t}$ of input logs [17,31] & $1.0[32]$ & $0.81[9,33]$ \\
Palm trunks & $3.0 \mathrm{t} / \mathrm{ha} \mathrm{[19]}$ & $0.9[20]$ & $0.9[34]$ \\
Palm fronds & $7.75 \mathrm{t} / \mathrm{ha} \mathrm{[35]}$ & $0.1[20]$ & $0.4[36,37]$ \\
Rice straw & $2.6 \mathrm{t} / \mathrm{ha} \mathrm{[24]}$ & $0.65[29]$ & $0.1[38]$ \\
Cocoa branches & $23 \mathrm{t} / \mathrm{ha} \mathrm{[9,39]}$ & $0.5[9]$ & 0 \\
Rubber branches & $0.47 \mathrm{t} / \mathrm{t}[9,33]$ & $0.5[9]$ & 0 \\
Coconut trunks & $0.19 \mathrm{t} / \mathrm{ha}[40,41]$ & $0.5[9]$ & 0 \\
Coconut fronds & $0.17 \mathrm{t} / \mathrm{ha}[9,41]$ & $0.5[9]$ & $0.9[9]$ \\
Logging residues & $0.39 \mathrm{t} / \mathrm{t}$ log produced [9,17] & $0.65[27]$ & 0 \\
\hline
\end{tabular}

\subsection{Biomass Locations and Distance to Coal Plants}

The locations of biomass were estimated using three approaches: (i) addresses for rice mills, sawmills and plywood mills and coordinates for landfills; (ii) assumed locations at the center of administrative districts for palm-oil mills; and (iii) centers of areas represented by polygons from GIS maps for rice straw, cocoa and rubber branches, oil-palm and coconut fronds and trunks, and logging areas. Field-based residues locations were determined by digitizing an image (jpeg format) of a land-use map of Peninsular Malaysia for the year 2006 obtained from the Department of Agriculture, Malaysia [15] using ArcGIS [42]. Altogether there were 8372 locations for plantations and logging areas and 1214 locations for mills and landfills for Peninsular Malaysia. The locations of the four coal-fired power plants were also projected using their coordinates.

Distances from biomass residues to the four coal power plants were estimated using the network analysis tool in the ArcGIS software. The tool generated a matrix of the shortest road distance using existing road network data obtained from the Malaysian Center for Geospatial Data Information.

\subsection{Electricity Generation}

Approximately 37 million MWh (32\%) of electricity was produced from coal in Malaysia in 2008 [2], which is the latest data available. However, the publication did not breakdown data by plant. Malaysia's coal plants have an average efficiency of about 37\% [2]. To estimate the electricity generation for each coal plant in Peninsular Malaysia, the installed capacity of each coal plant was used to allocate the total generation to individual plants. Because about $94 \%$ (by capacity) of the coal-fired electricity generation is located in Peninsular Malaysia [2], 35 million MWh were assumed generated by the four coal plants in this region. Each coal plant was assumed to have generated between 6.9 and 10.3 million MWh. 


\subsection{Optimization Model}

A linear optimization model was developed to estimate the total cost and GHG emissions associated with biomass coal co-firing in Peninsular Malaysia. Minimization of total costs and GHG emissions were evaluated in separate models. Analytica Optimizer version 4.4.2.2 from Lumina Decision Systems that incorporates Frontline's large-scale linear solver engine version 11 was used for the analysis [43]. The mathematical formulation is as follows:

Minimize cost:

$$
\begin{gathered}
C=\sum_{t \in T} \sum_{i \in N_{t}} \sum_{j \in J} c_{t} x_{i, j}^{t}+\sum_{t \in T} \sum_{i \in N_{t}} \sum_{j \in J} d_{i, j}^{t} c_{i, j}^{t} x_{i, j}^{t}+\sum_{j \in J} c_{j}^{\mathrm{COAL}} x_{j}^{\mathrm{COAL}} \\
+\sum_{j \in J} \sum_{l \in L} W_{j} c_{l}^{\mathrm{RET}} x_{j, l}^{\mathrm{RET}}
\end{gathered}
$$

(from biomass purchase + biomass transport + coal purchase and transport + plant retrofit) or

Minimize GHGs:

$$
G=\sum_{t \in T} \sum_{i \in N_{t}} \sum_{j \in J} g_{t} x_{i, j}^{t}+\sum_{t \in T} \sum_{i \in N_{t}} \sum_{j \in J} d_{i, j}^{t} g_{i, j}^{t} x_{i, j}^{t}+\sum_{j \in J} g_{j}^{\mathrm{COAL}} x_{j}^{\mathrm{COAL}}
$$

(from biomass pre-treatment + biomass transport + coal transport, pre-treatment and combustion)

With respect to:

$x_{i, j}^{t} \in \mathbb{R} \forall i \in N_{t}, j \in J, t \in T \quad$ Quantity of each residue type $t$ shipped from each

$x_{j}^{\mathrm{COAL}} \in \mathbb{R} \forall j \in J$

$x_{j, l}^{\mathrm{RET}} \in \mathbb{R} \forall j \in J, l \in L$

Subject to:

$$
\begin{aligned}
& \sum_{j \in J} x_{i, j}^{t} \leq s_{i}^{t} \\
& \forall t \in T, i \in N_{t} \\
& \sum_{t \in T} \sum_{i \in N_{t}} \eta_{t} x_{i, j}^{t}+\eta_{\mathrm{C}} x_{j}^{\mathrm{COAL}}=E_{j} \\
& \forall j=J \\
& \sum_{t \in T} \sum_{i \in N_{t}} \eta_{t} x_{i, j}^{t}=E_{B} \\
& \sum_{t \in T} \sum_{i \in N_{t}} \eta_{t} x_{i, j}^{t} \leq E_{j} \sum_{l \in L} x_{j, l}^{\mathrm{RET}} r_{l} \\
& \forall j=J
\end{aligned}
$$
supply location $i$ to each plant $j(\mathrm{t})$ Quantity of coal shipped to each plant $j(\mathrm{t})$ Variables defining the portion of plant $j$ 's capacity that is retrofitted to co-fire biomass, where $l$ indexes distinct levels of retrofit for modeling a piecewise linear (convex hull of five points) cost curve (\%)

At each supply location the use of biomass resources must not exceed its supply limit (t).

The sum of electricity generated from biomass and coal at each plant must be equal to the total required (amount generated in the year 2008).

The total energy generated from biomass should be $\mathrm{EB}=2$ million MWh in one scenario. This constrained is omitted for the Optimal Residue Use scenario.

The total biomass generation at each plant must be within the co-firing capacity of that plant. 


$$
\begin{aligned}
& x_{i, j}^{t}, x_{j}^{\mathrm{COAL}} \geq 0 \\
& 0 \leq x_{j, l}^{\mathrm{RET}} \leq 1 \\
& \sum_{l \in L} x_{j, l}^{\mathrm{RET}} \leq 1 \\
& \forall j=J, l \in L, t \in T
\end{aligned}
$$

Quantities must be nonnegative, and the retrofit variables are bound between zero and one with sum not greater than one to formulate the piecewise linear cost curve in the objective (convex hull of points $\{(0 \%$, $\$ 0 / \mathrm{kW}),(2 \%, \$ 100 / \mathrm{kW}),(10 \%, \$ 200 / \mathrm{kW}),(20 \%$, $\$ 300 / \mathrm{kW}),(100 \%, \$ 2000 / \mathrm{kW})[44,45]$. The retrofit capital cost is annualized over a 40 year assumed remaining life span of coal plants using a $4 \%$ discount rate [46-48].

where $N_{t}=\left\{1,2, \ldots, n_{t}\right\}$ is the set of supply locations for biomass residue type $t$; $T$ and $n_{t}$, are the set of biomass residue types and the number of locations for each type, respectively (See Table 1 in the supporting information for more detail); $J=\{1,2,3,4\}$ is the set of coal plants; $L=\{1,2,3,4\}$ is the set of co-firing retrofit levels in the piecewise linear retrofit cost curve; $c_{t}$ is the purchase cost $(\$ / t)$ of biomass type $t ; d_{i, j}^{t}$ is the distance $(\mathrm{km})$ from biomass $t$ location $i$ to plant $j ; c_{i, j}^{t}$ is the cost $(\$ / \mathrm{t})$ for shipping biomass type $t$ from location $i$ to plant $j ; c_{j}^{\mathrm{COAL}}$ is the cost $(\$ / \mathrm{t})$ for purchase, transport, and pre-treatment of coal for plant $j$. Other coal plant operation and maintenance costs (labor, environmental controls, etc.) are assumed constant with respect to co-firing rate and are thus not included in the cost estimation for the purpose of comparing the cost of co-firing vs. coal-only electricity generation; $W_{j}$ is the capacity of plant $j(\mathrm{MW}) ; c_{l}^{\mathrm{RET}}=\$\{100,200,300,2000\} / \mathrm{kW}$ for $l=\{1,2,3,4\}$, respectively, is the cost per unit capacity of retrofitting plant $j$ at breakpoint level $l$ of the piecewise linear cost curve; $g_{t}$ is the emissions intensity $\left(\mathrm{tCO}_{2} \mathrm{eq} / \mathrm{t}\right)$ from pre-treatment of biomass type $t ; g_{i, j}^{t}$ is the emissions intensity $\left(\mathrm{tCO}_{2} \mathrm{eq} / \mathrm{t} \cdot \mathrm{km}\right)$ of shipping from biomass type $t$ location $i$ to plant $j ; g_{j}^{\mathrm{COAL}}$ is the emissions intensity $\left(\mathrm{tCO}_{2} \mathrm{eq} / \mathrm{t}\right)$ of pre-treating, transporting and combusting coal; $s_{i}^{t}$ is the maximum supply of biomass type $t$ at location $i(\mathrm{t}) ; \eta_{t}$ is the efficiency of converting biomass type $t$ into electricity $(\mathrm{MWh} / \mathrm{t}) ; \eta_{\mathrm{C}}$ is the efficiency of converting coal into electricity $(\mathrm{MWh} / \mathrm{t}) ; E_{j}$ is the annual electricity generation of plant $j(\mathrm{MWh}) ; E_{\mathrm{B}}$ is the biomass co-firing capacity target; and $r_{l}=\{2 \%, 10 \%, 20 \%, 100 \%\}$ for $l=\{1,2,3,4\}$, respectively, is the retrofit portion at each level $l$ (breakpoint) of the piecewise linear cost curve.

We also minimized the total cost and emissions for coal-only electricity generation $\left(x_{i, j}^{t}=x_{j, l}^{\mathrm{RET}}=0 \forall i \in N_{t}, j \in J, t \in T, l \in T\right)$ as a reference case, to compare its total cost with total cost of co-firing.

\subsection{Greenhouse Gas Emissions Modeling}

Life cycle GHG emissions factors were derived from various sources and are shown in Table 2. 
Table 2. Important cost parameters and ranges used in the model.

\begin{tabular}{|c|c|c|c|c|c|c|c|}
\hline Symbol & Parameter & Unit & Distribution & Min & Most likely & Max & Note \\
\hline$c_{t}$ & Palm EFB & $\$ / \mathrm{t}$ & Triangular & $\$ 1.80$ & $\$ 5$ & $\$ 6.70$ & {$[49]$} \\
\hline$c_{t}$ & Palm shell & $\$ / \mathrm{t}$ & - & - & $\$ 16.70$ & - & [49] \\
\hline$c_{t}$ & Palm fiber & $\$ / \mathrm{t}$ & Triangular & $\$ 2.30$ & $\$ 5.50$ & $\$ 7.20$ & $\begin{array}{l}\text { [49] The price of EFB used as surrogate and adjusted based on the } \\
\text { energy content. }\end{array}$ \\
\hline$c_{t}$ & Rice husk & $\$ / \mathrm{t}$ & Uniform & $\$ 4.70$ & - & $\$ 11.80$ & [50] Data is adapted from a case study in the Philippines. \\
\hline$c_{t}$ & Paper-based MSW & $\$ / \mathrm{t}$ & - & - & $\$ 1.90$ & - & $\begin{array}{l}{[44,45] \text { Tipping fee for MSW in Malaysia - } \$ 1.20 / \mathrm{t} \text { in } 1994 \text {. A GDP }} \\
\text { deflator used to convert to } \$ 2010 \text {. A } 10 \% \text { premium added. }\end{array}$ \\
\hline$c_{t}$ & Sawmill residues & $\$ / \mathrm{t}$ & - & - & $\$ 7.40$ & - & [47] Eucalyptus wood waste in Thailand used as surrogate. \\
\hline$c_{t}$ & Plywood mill residues & $\$ / \mathrm{t}$ & - & - & $\$ 7.40$ & - & [47] Eucalyptus wood waste in Thailand was used as surrogate. \\
\hline$c_{t}$ & Palm trunks & $\$ / \mathrm{t}$ & Triangular & $\$ 1.90$ & $\$ 5.10$ & $\$ 6.80$ & $\begin{array}{l}\text { [49] The price of EFB used as a surrogate and adjusted based on the } \\
\text { energy content. }\end{array}$ \\
\hline$c_{t}$ & Palm fronds & $\$ / \mathrm{t}$ & Triangular & $\$ 1.40$ & $\$ 4.60$ & $\$ 6.30$ & $\begin{array}{l}\text { [49] The price of EFB used as a surrogate and adjusted based on the } \\
\text { energy content. }\end{array}$ \\
\hline$c_{t}$ & Rice straw & $\$ / \mathrm{t}$ & - & - & $\$ 14.90$ & - & $\begin{array}{l}{[46,50] \text { Cost of collecting and baling of rice straw in Thailand used as }} \\
\text { a surrogate. A premium of } 10 \% \text { is assumed. }\end{array}$ \\
\hline$c_{t}$ & Cocoa branches & $\$ / \mathrm{t}$ & Uniform & $\$ 13.50$ & - & $\$ 16.20$ & [47] Logging residues price used as surrogate. \\
\hline$c_{t}$ & Rubber branches & $\$ / \mathrm{t}$ & Uniform & $\$ 13.50$ & - & $\$ 16.20$ & [47] Logging residues price used as surrogate. \\
\hline$c_{t}$ & Coconut trunks & $\$ / \mathrm{t}$ & Triangular & $\$ 1.90$ & $\$ 5.10$ & $\$ 6.80$ & [49] Palm trunk price used as a surrogate. \\
\hline$c_{t}$ & Coconut fronds & $\$ / \mathrm{t}$ & Triangular & $\$ 1.40$ & $\$ 4.60$ & $\$ 6.30$ & [49] Palm trunk price used as a surrogate. \\
\hline$c_{t}$ & Logging residues & $\$ / \mathrm{t}$ & Uniform & $\$ 13.50$ & - & $\$ 16.20$ & {$[47]$} \\
\hline$c_{t}$ & Biomass drying & $\$ / \mathrm{t}$ & - & - & $\$ 2.50$ & - & [44] Assumed that excess heat used for biomass drying. \\
\hline$c_{t}$ & Biomass pulverizing & $\$ / \mathrm{t}$ & - & - & $\$ 8.50$ & - & $\begin{array}{l}{[51,52] \text { Cost is based on a } \$ 0.05 \text { per } \mathrm{kWh} \text { average industrial electricity }} \\
\text { rate in Malaysia. }\end{array}$ \\
\hline
\end{tabular}


Table 2. Cont.

\begin{tabular}{|c|c|c|c|c|c|c|c|}
\hline Symbol & Parameter & Unit & Distribution & Min & Most likely & Max & Note \\
\hline$c_{t}$ & Biomass storage & $\$ / \mathrm{t}$ & Uniform & $\$ 5.25$ & - & $\$ 10.30$ & [53] Corn and switchgrass residues storage cost used as a surrogate. \\
\hline$c^{t}$ & $\begin{array}{c}\text { Variable biomass } \\
\text { transportation costs- } \\
\text { high bulk density }\end{array}$ & $\$ /$ t.km & Uniform & $\$ 0.111$ & - & $\$ 0.23$ & [44,54] Palm EFB used as a surrogate for high bulk density residues. \\
\hline$c^{t}$ & $\begin{array}{c}\text { Variable biomass } \\
\text { transportation costs- } \\
\text { low bulk density }\end{array}$ & $\$ /$ t.km & Uniform & $\$ 0.131$ & - & $\$ 0.58$ & {$[44,54,55]$ Scaled for bulk density of rice residues to EFB bulk density. } \\
\hline$c_{t}$ & $\begin{array}{l}\text { Fixed biomass } \\
\text { transportation costs }\end{array}$ & $\$ / \mathrm{t}$ & Uniform & $\$ 3.60$ & - & $\$ 5.00$ & {$[54,56]$} \\
\hline$c^{\text {coal }}$ & Coal & $\$ / \mathrm{t}$ & Triangular & $\$ 25$ & $\$ 60$ & $\$ 127$ & {$[57]$} \\
\hline$c^{\text {coal }}$ & Coal pulverizing & $\$ / \mathrm{t}$ & Uniform & $\$ 0.60$ & - & $\$ 1.10$ & $\begin{array}{l}{[52,58] \text { Cost estimation is based on } \$ 0.05 / \mathrm{kWh} \text {, the average industrial }} \\
\text { electricity rate in Malaysia. }\end{array}$ \\
\hline$c^{\text {coal }}$ & Coal storage & $\$ / \mathrm{t}$ & - & - & $\$ 6.30$ & - & {$[45,59]$ GDP deflator was used to estimate the $\$ 2010$} \\
\hline$c^{\text {coal }}$ & Coal shipping & $\$ /$ t.km & - & - & $\$ 0.002$ & - & {$[60]$} \\
\hline$c^{R E T}$ & $\begin{array}{l}\text { Coal plant retrofit at } 2 \% \\
\text { co-firing rate }\end{array}$ & $\$ / \mathrm{kW}_{\mathrm{b}}$ & Triangular & $\$ 50$ & $\$ 100$ & $\$ 150$ & {$[61,62]$} \\
\hline$c^{R E T}$ & $\begin{array}{l}\text { Coal plant retrofit at } 10 \% \\
\text { co-firing rate }\end{array}$ & $\$ / \mathrm{kW}_{\mathrm{b}}$ & Triangular & $\$ 150$ & $\$ 200$ & $\$ 250$ & {$[61,62]$} \\
\hline$c^{R E T}$ & $\begin{array}{l}\text { Coal plant retrofit at } 20 \% \\
\text { co-firing rate }\end{array}$ & $\$ / \mathrm{kW}_{\mathrm{b}}$ & Triangular & $\$ 250$ & $\$ 300$ & $\$ 350$ & $[61,62]]$ \\
\hline$c^{R E T}$ & $\begin{array}{c}\text { Coal plant retrofit cost at } \\
100 \% \text { co-firing rate }\end{array}$ & $\$ / \mathrm{kW}_{\mathrm{b}}$ & - & - & $\$ 2,000$ & - & {$[62]$} \\
\hline
\end{tabular}


Residues are generally considered as having no emissions associated with their production [63]. However, there is some debate as to whether allocation of emissions is necessary when the residue becomes a product, e.g., being sold as a fuel. To avoid this argument all emissions associated with the production of the commodity were allocated to the residue (for instance, emissions associated with rice production were all allocated to the rice husk). This obviously over estimates the emissions associated with residue use and reduces any emissions savings modeled here. Additionally, this conservative approach makes wood-based MSW have higher GHG emissions per unit energy than coal (0.33 $\mathrm{tCO}_{2}$-eq/GJ vs. $0.29 \mathrm{tCO}_{2}$-eq/GJ). Thus, while optimizing for GHG emissions these residues would never be chosen by the model. This would reduce the maximum value of emissions reductions obtainable as estimated here.

The emissions factor for coal includes combustion emissions and weighted transportation emissions from Indonesia, Australia and South Africa (see Table 2 in the Supplemental Information). With the sources of coal coming from multiple countries and little or no data available for mining practices in all of these countries, mining emissions were ignored. Using U.S. coal production as a guide, the exclusion of these emissions underestimates the overall life cycle emissions of coal by less than $4 \%$ [64].

\section{Results and Discussion}

\subsection{Residue Amount}

Fifty-five percent of residues are field-based, those which are derived from agriculture activities and move directly from the "field" to the power plant. The remaining residues are process-based, originating at mills (Figure 1). This is an important distinction. Generally, Peninsular Malaysia has a developed transportation system that supports a mill's activity, whereas agricultural areas may have only limited transportation infrastructure.

Residues available for co-firing are estimated at about $12 \mathrm{Mt} /$ year (Figure 1). Oil palm is the largest source of these residues $(77 \%$ of the total), followed by rice $(9.1 \%)$ and forestry residues $(8.2 \%)$. The remaining residues $(5.7 \%)$ are available in relatively small amounts and include, in decreasing order of availability, wood-based MSW, rubber, cocoa, and coconut residues. The latter two sources are negligible.

Oil palm and palm oil production accounts for just over $9 \mathrm{Mt}$ per annum of residues. This is 8 -fold larger than the second largest source-rice production. Palm oil residues are larger by category (field-based and process-based) compared to any other source. Also, palm oil production results in 18 times more process-based residue than rice production and is 9 times greater than the next largest source of process-based residues-MSW. 
Figure 1. Yearly residues (Mt) by type available for co-firing in Peninsular Malaysia. The error bars for the total residues represent 5 th and 95 th percentile values.

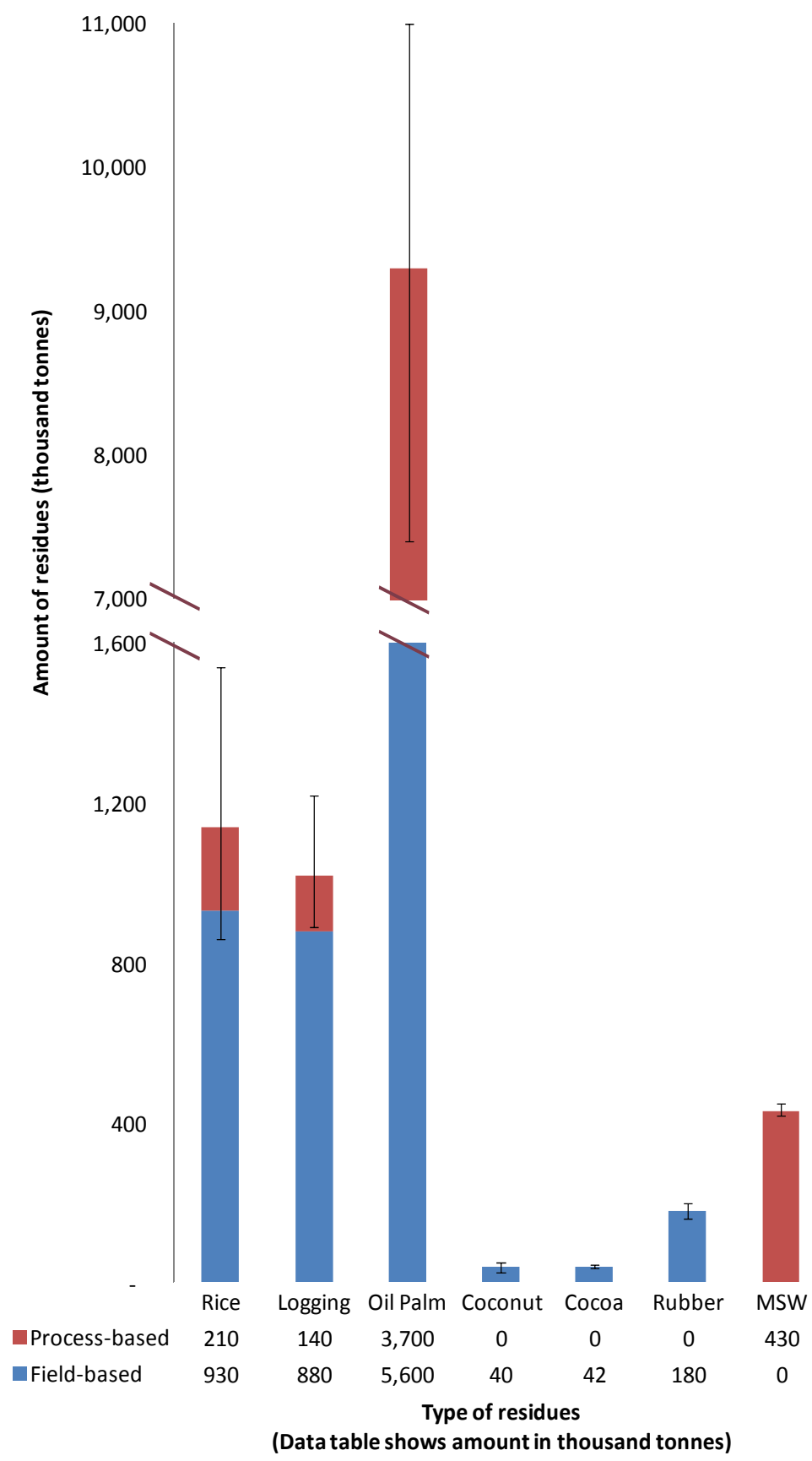

\subsection{Distribution and Locations of Biomass Residues}

Figure 2 shows the locations of the residue resources available in Peninsular Malaysia. Field-based residues (Figure 2a) have a wide distribution along coastal areas, particularly on the west coast. There is some concentration of residues in the southern part of the peninsula where $53 \%$ of the country's palms are grown [35]. Forest covers 54\% of Peninsular Malaysia, but logging occurs only in small areas (green coloration in Figure 2a) with the largest areas in the central and southeastern sections of the country. Generally, mills are co-located near their feedstock source (e.g., palm-oil mills are located in area where palm is grown) (compare Figure 2a with Figure 2b). However, sawmills and plywood mills are an exception where they are located near their markets, towns and cities. 
Figure 2. Locations of residues in Peninsular Malaysia: (a) field-based residues; (b) process-based residues. Values in parenthesis in (b) represent the number of mills/landfill.
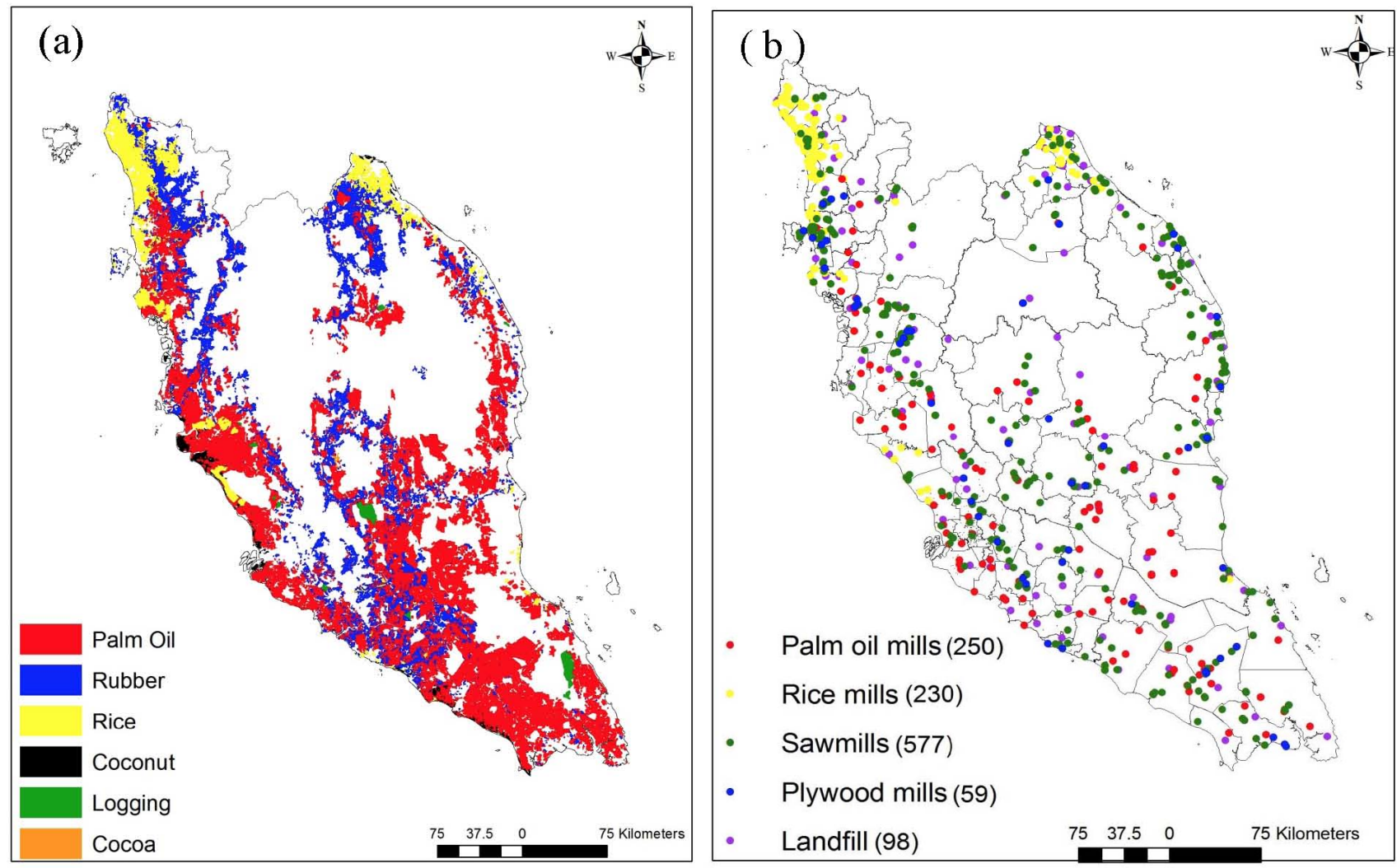

Generally, the highest residue quantities are found in the southeast region of the country (Figure 3a). However, the coal fired electricity power plants are located along the western coast of Peninsular Malaysia (Figure 3b, solid red circles) adding a significant transportation component for the use of biomass for co-firing. If direct biomass firing was used, the plants could be located closer to the sources of biomass as long as co-location cost reduction where not offset by addition transmission infrastructure. These trade-offs were not investigated here.

Figure $3 \mathrm{~b}$ also shows the road network in Peninsular Malaysia. In the southeast region where the residues are the most dense the road network is the least developed. Using "road density," defined here as road length within an administrative district over the total area $\left(\mathrm{km} / \mathrm{km}^{2}\right)$ of that district, as a guide, the southeast has road densities between 0.1 and $0.2 \mathrm{~km} / \mathrm{km}^{2}$ whereas on the west coast, where less residues are available, have a road density higher than the southeast, between 0.45 and $0.69 \mathrm{~km} / \mathrm{km}^{2}$. Most likely an improved transportation system in some areas will be required to efficiently supply residues for co-firing. The anticipated costs of expanded infrastructure are not modeled. However, to some extent any new costs could be offset by additional social benefits accruing over time due to improved infrastructure in rural communities. 
Figure 3. Amount of residues in relation to coal-fired power plants and road infrastructure in Peninsular Malaysia (a) residues distribution by weight; (b) the road network and locations of coal power plants.

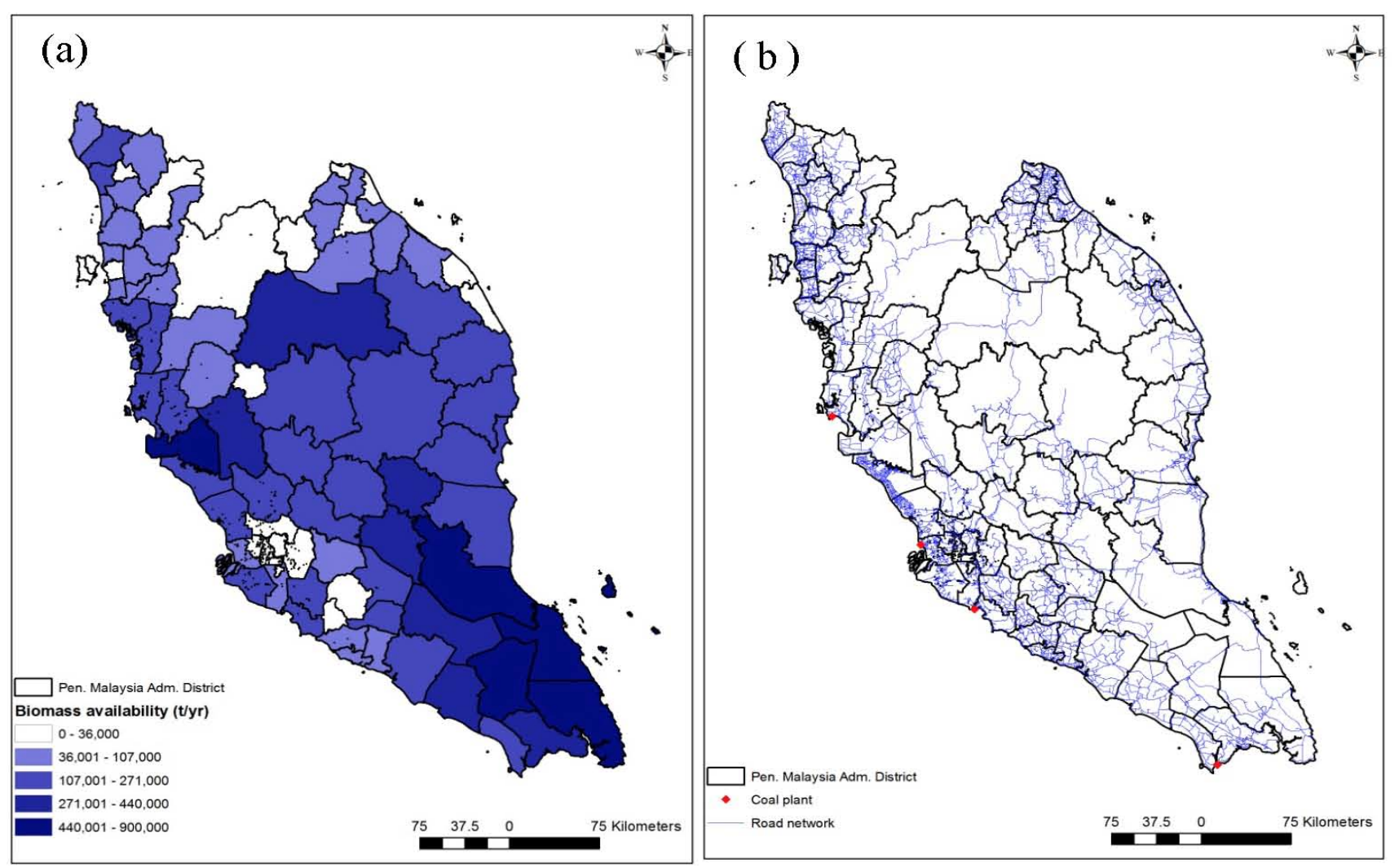

\subsection{Costs of Co-Firing}

The Limited Co-firing Scenario generates an equivalent of 2.0 million MWh from biomass residues to meet the Malaysian biomass electricity policy and costs approximately $\$ 1.14$ billion (Table 3 ). This is \$20 million less than the Reference Case of producing this same amount of electricity from coal, based on a coal price of $\$ 85 / \mathrm{t}$. Limited Co-firing has $\$ 41$ million of biomass related costs (purchase, transport, and electricity plant associated costs e.g., moving biomass within the plant boundary, etc.). Coal use is reduced and results in about $\$ 65$ million less foreign coal purchases. The transfer of foreign expenditures (coal purchases) to local expenses could have a significant stimulus to the local economy. Quantifying the exact impacts of such a transfer requires a detailed economic assessment and is beyond the scope of this analysis.

A dedicated biomass fired power plant capable of generating 2.0 million MWh of electricity has capital costs (land, buildings, equipment, etc.) estimated at between $\$ 495$ and $\$ 990$ million [12]. Assuming that all of the associated biomass costs (feedstock, transport, and onsite movements) are the same for a dedicated biomass power generation and co-firing and using a simple $100 \%$ equity-financing strategy, the yearly capital recovery costs for a dedicated biomass power plant would be on the order of $\$ 25$ million. This far exceeds the $\$ 4$ million annual capital charge associated with co-firing (Table 3). Also, financing costs would likely be higher than estimated here because partial debt financing would be preferred for such a capital-intensive project. Overall, it is likely that direct biomass firing costs would exceed those of co-firing. 
Table 3. Costs and co-firing capacity for coal fired electricity production and co-firing scenarios using parameter point estimates.

\begin{tabular}{ccccc}
\hline \multirow{2}{*}{ Model output } & \multicolumn{4}{c}{ Scenario } \\
\cline { 2 - 5 } & $\begin{array}{c}\text { Coal-fired generation } \\
\text { (Reference case) }\end{array}$ & $\begin{array}{c}\text { Limited co-firing } \\
\mathbf{( 2 . 0} \text { million MWh) }\end{array}$ & $\begin{array}{c}\text { Optimal co-firing } \\
\text { (minimum cost) }\end{array}$ \\
\hline \multirow{3}{*}{ Costs (\$millions) } & Biomass & 0 & 41 & 150 \\
& Coal & 1160 & 1095 & 950 \\
& Retrofit & 0 & 4 & 15 \\
& Total & 1160 & 1140 & 1125 \\
\hline Co-firing capacity (MW) & 0 & 330 & 1040 \\
\hline
\end{tabular}

The Limited Co-firing Scenario requires $9 \%$ of the total available biomass residue. Because Malaysia potentially has abundant residues and to understand the full potential of biomass co-firing, the model was allowed to minimize costs without constraining biomass use at those needed for $330 \mathrm{MW}$ of capacity. This provides an estimate of the maximum potential cost savings from reducing coal use with biomass (Optimal Co-firing, see Table 3). Here, 29\% of the $12.2 \mathrm{Mt}$ of available residues is consumed, providing over 6 million MWh of electricity and reducing $\mathrm{CO}_{2}$ emission by about 5.7 Mt. The overall costs are reduced by $\$ 35$ million compared to using coal alone.

\subsection{GHG Emissions of Co-Firing}

The current policy of installing $330 \mathrm{MW}$ of biomass electricity capacity also targets $1.3 \mathrm{Mt}$ of $\mathrm{CO}_{2}$ emissions reduction by 2015 [65]. The Limited Co-firing scenario reduces emissions by $1.9 \mathrm{Mt}$ of $\mathrm{CO}_{2}$ compared to Coal-fired Generation (Table 4), exceeding the government's target. Because co-firing can reduce emissions at lower costs than current coal fired electricity generation, the obvious question is - what is the optimal GHG emissions savings?

Optimal cost scenarios may opt for lower cost residues further from a power plant if the residue cost savings offsets transportation costs. However, when optimizing life cycle GHG emissions, the emissions impact from transportation penalizes longer transportation legs. To capture this dynamic an unconstrained biomass scenario was modeled that minimized GHG emissions from co-firing (Optimal GHG Emissions, Table 4). The scenario resulted in a $17 \mathrm{Mt}$ of $\mathrm{CO}_{2}$ reduction compared to coal-fired generation. Under this scenario Malaysia could reduce its total GHG emissions based on 2010 data between $1.1 \%$ and $9.4 \%$, but it comes with increased cost for generating electricity.

The $330 \mathrm{MW}$ scenario eliminated $1.9 \mathrm{Mt} /$ year of $\mathrm{CO}_{2}$ emissions at a lower cost compared to the reference case, thus has a negative of cost of mitigation (COM) (Table 4). For the Optimal GHG scenario the $\mathrm{COM}$ is $\$ 23 / \mathrm{tCO}_{2}$ mitigated. To put this value in perspective, the Malaysian government has imposed a levy on heavy electricity users (those using $>350 \mathrm{kWh} / \mathrm{month}$ ), which is intended to collect about $\$ 100$ million/year to subsidize the installation of the $975 \mathrm{MW}$ of renewable electricity [65]. With the government estimate that $3.7 \mathrm{Mt}$ of $\mathrm{CO}_{2}$-eq/year could be avoided [66], the levy payments imply a $\mathrm{COM}$ of about $\$ 27 / \mathrm{t} \mathrm{CO}_{2}$-eq.

The COM from increasing use of co-firing is lower than the levy's implied COM by $\$ 5 / \mathrm{t} \mathrm{CO}_{2}$-eq., making co-firing a better alternative to the levy-subsidy approach on a per tonne basis. However, the annual expenditure would increase the total costs of reducing emissions to over $\$ 400$ million. 
If one assumes linearity of the optimization model used here, then at a cost of $\$ 100$ million, the same as revenue raised by the levy, $6 \mathrm{Mt}$ of $\mathrm{CO}_{2}$-eq/year of emissions reduction could be achieved via co-firing, a third more effective than investment in a general renewables portfolio strategy envisioned by the levy policy.

Table 4. GHG emissions and cost of carbon mitigation for coal and co-firing scenarios.

\begin{tabular}{|c|c|c|c|c|}
\hline \multicolumn{2}{|c|}{ Model output } & $\begin{array}{c}\text { Coal-fired generation } \\
\text { (Reference case) }\end{array}$ & $\begin{array}{l}\text { Limited co-firing } \\
\text { (2.0 million MWh) }\end{array}$ & $\begin{array}{c}\text { Optimal co-firing } \\
\text { Scenario-GHG Emissions }\end{array}$ \\
\hline \multirow{3}{*}{ GHG emissions (Mt) } & Total & 36.2 & 34.3 & 19 \\
\hline & Biomass & 0 & 0.15 & 2.1 \\
\hline & Coal & 36.2 & 34.1 & 16.8 \\
\hline \multicolumn{2}{|c|}{$\begin{array}{l}\text { Cost of carbon mitigation } \\
\left(\$ / \mathrm{CO}_{2}-\mathrm{eq}\right)\end{array}$} & 0 & -2.40 & 22.5 \\
\hline \multicolumn{2}{|c|}{ Co-firing capacity (MW) } & 0 & 330 & 3090 \\
\hline
\end{tabular}

${ }^{1}$ This scenario represents the upper bound of upstream GHG emissions from co-firing.

The Malaysian government has imposed a levy on heavy electricity users (those using $>350 \mathrm{kWh} /$ month), which is intended to collect about $\$ 100$ million/year to subsidize the installation of $975 \mathrm{MW}$ of renewable electricity by 2015 [21]. The government estimates that $3.7 \mathrm{Mt}$ of $\mathrm{CO}_{2}$-eq/year could be avoided [19]. The levy payments imply a COM of about $\$ 27 / \mathrm{CO}_{2}$-eq. In this study, the optimal GHG emissions scenario results in a $17 \mathrm{Mt}$ of $\mathrm{CO}_{2}$-eq/year reduction in emissions with a COM of $\$ 22.5 / \mathrm{CO}_{2}$-eq. This COM is lower than the levy's implied COM by $\$ 5 / \mathrm{t} \mathrm{CO}_{2}$-eq. making co-firing a better alternative to the levy-subsidy approach on a per tonne basis. The annual expenditure would be $\$ 280$ million more than the levy-subsidy approach but would achieve an almost 5-fold greater reduction in GHG emissions.

Reducing GHG emissions beyond those that are possible at a break-even cost from current coal-firing economics are unlikely to occur without government action. An alternative to the levy-subsidy approach it the use of a carbon tax. Figure 4 shows a Pareto curve summarizing the effect of different carbon prices on GHG emissions and the direct costs (excluding carbon taxes) of the resulting cost-minimum solutions. Based on this analysis, at a carbon price of $\$ 20 / t$ the direct cost to the industry increases by about $\$ 38$ million but electricity generation emits about $5.5 \mathrm{Mt}$ less GHG than when there is no carbon price. In addition, the government would collect about $\$ 440$ million/year from the tax. The tax could be used to fund other measures to reduce GHG emissions, such as rebates to users of energy efficient equipment/appliances or simply a rebate to poor income households to offset the higher utility charges. In any case, Malaysia can choose between a number of different programs to achieve GHG emission reductions via biomass residue co-firing. 
Figure 4. Net cost and industry cost of optimal systems under various carbon prices. The net cost curve represents the Pareto tradeoff between cost and emissions. The difference between the curves is the carbon tax transfers to the government.

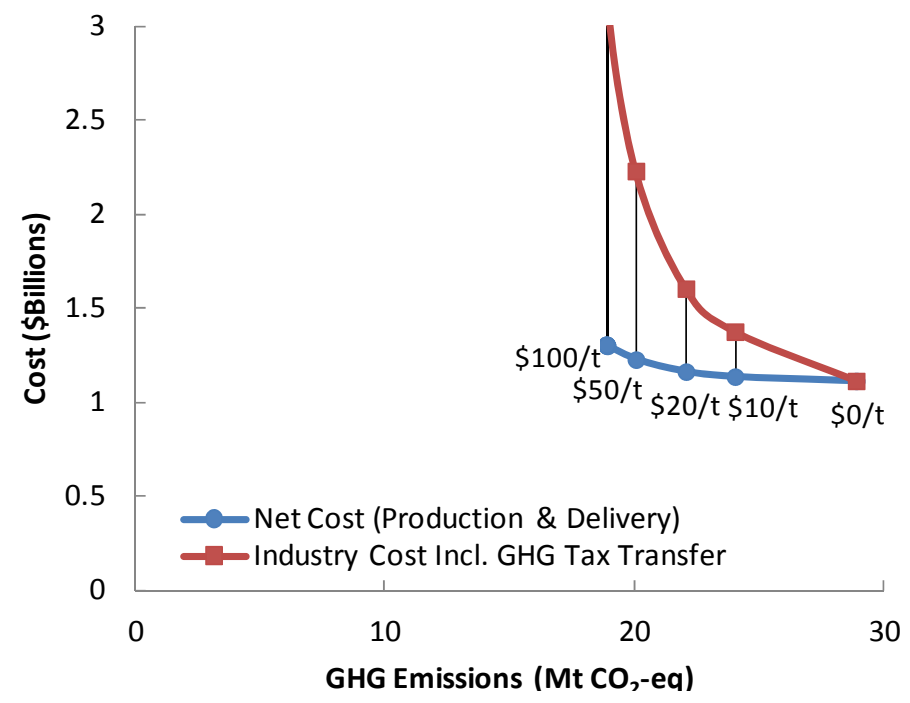

\subsection{Study Limitations}

This study focuses on private costs and does not quantify externalities related to adopting co-firing. For instance, increased vehicle use to transport biomass will require increased road maintenance, presently borne by the government. There are positive externalities that will accrue to society from balance of trade accounts due to lower imported coal use. Additionally, improving rural infrastructure and increasing rural income will bring un-quantified benefits. These and other impacts will need to be analyzed to provide a complete understanding of co-firing's potential.

This analysis was a scoping study of co-firing in the Malaysian context. There are assumptions and limitations due to study design that could impact results. They include: (i) all existing biomass used in biomass firing plants is considered fixed. It is possible that there exists a better solution where some of this biomass might be rerouted for co-firing and other biomass taken to nearby direct biomass firing plants. However, we do not expect these considerations to change results substantially because the current dedicated biomass power plants generate a small amount of energy (1.5 million MWh); (ii) other uses of residues are considered fixed/exogenous. If co-firing affects prices, this could change the portion of residues sold for these other uses. Residue price increases might make co-firing less attractive; (iii) timing is ignored. It is assumed that if a sufficient amount of biomass is shipped for the year then it can deliver the annual electricity required. Biomass supply varies seasonally, and the potential for storage is limited, so co-firing availability could vary throughout the year, and co-firing could make the electricity sector more susceptible to weather related events; and (iv) finally, biomass can provide energy and displace fossil fuel use by many alternative pathways. Cellulosic ethanol, for instance, could provide a transportation fuel that displaces gasoline use or, alternatively, biomass gasification could provide a suite of distillates for diesel or jet fuel production that could displace their fossil based counterparts. Each of these pathways might provide greater benefits to society than biomass co-firing. However, with the cost based scenarios described here only about $30 \%$ of the available residues were consumed, which leaves considerable latitude for Malaysia to develop other approaches to biomass use and/or GHG emissions reductions while benefiting from co-firing. 


\section{Conclusions}

Malaysia intends to install 975 MW of renewable electricity that will include 330 MW generated from biomass and offset the some climate impacts of increasing coal use by reducing $\mathrm{CO}_{2}$ emission by 1.3 Mt. This study looked at the use of biomass - coal co-firing as an alternative to biomass direct combustion to provide the $330 \mathrm{MW}$ of biomass electricity generation capacity.

Malaysia has abundant biomass residues. This analysis demonstrates that there are about $12 \mathrm{Mt} / \mathrm{year}$ of residues that could be collected and used for energy production, while accounting for all current competitive uses of the resource. Although the generation requirement investigated here is fixed there's enough biomass residues to meet increased future needs. The $330 \mathrm{MW}$ of co-firing scenario uses $9 \%$ of the total available residues.

This work showed that co-firing at the $330 \mathrm{MW}$ level can reduce the annual electricity generation costs by of up to $\$ 20$ million compared to current coal fired generation and reduce $\mathrm{CO}_{2}$ emissions by $1.9 \mathrm{Mt}$ of GHG emissions resulting in a negative cost of COM. Optimally the capacity could be increased to slightly over $1000 \mathrm{MW}$, result in \$35 million annually cost savings compared to coal use, and will reduce emissions by 5.7 Mt. This would exceed the entire renewables target of $975 \mathrm{MW}$ of capacity. Direct biomass firing has capital expenditures for the new facilities and transmission costs associated with its development. Much of this is eliminated using a co-firing approach.

The use of biomass co-firing reduces imports of coal by $\$ 65$ million annually when meeting the 330 MW level, thus transferring foreign exchange into domestic economic activity. Biomass production occurs largely in rural areas and increased economic activity can provide a multitude of benefits. The supply chain, however, will require additional transportation infrastructure development the costs of which were not modeled here.

Biomass has multiple uses and those need to be investigated to assure that these resources are used most efficiently. However, these results provide an important foundation for formulating renewable electricity policy in Malaysia.

\section{Acknowledgments}

This work was support in part under the Government of Malaysia's In-service Training Award 2008 Ref: A1764528, the Carnegie Mellon University Green Design Institute and the Climate and Energy Decision Making Center (CEDM) (SES-0949710), formed through a cooperative agreement between the NSF and CMU. We would also like to extend our appreciation to Matt Kocoloski at Carnegie Mellon University for the input on the modeling work.

\section{Conflicts of Interest}

The authors declare no conflict of interest.

\section{References}

1. Ministry of Energy Green Technology and Water. National Energy Balance 2009 Malaysia; Malaysian Green Technology Corporation: Putrajaya, Malaysia, 2009. 
2. Energy Commission Malaysia. Electricity Supply Industry in Malaysia-Performance and Statistcial Information 2008; Energy Commission Malaysia: Kuala Lumpur, Malaysia, 2009.

3. The Institute of Energy Economics, Japan. The 2nd ASEAN Energy Outlook; The Institute of Energy Economics: Tokyo, Japan, 2009. Available online: http://www.energycommunity.org/ documents/SecondASEANEnergyOutlook.pdf (accessed on 6 October 2011).

4. International Energy Agency. Key World Energy Statistics; International Energy Agency: Paris, France, 2010. Available online: http://www.iea.org/textbase/nppdf/free/2010/key_stats_2010.pdf (accessed on 6 September 2011).

5. Ministry of Natural Resources and Environment Malaysia. Second Malaysia National Communication to the UNFCC; Ministry of Natural Resources and Environment: Putrajaya, Malaysia, 2011.

6. Weisser, D. A guide to life-cycle greenhouse gas (GHG) emissions from electric supply technologies. Energy 2007, 32, 1543-1559.

7. Asia Pacific Economic Cooperation. APEC Energy Demand and Supply Outlook 2006-Malaysia; Asia Pacific Economic Cooperation: Tokyo, Japan, 2006. Available online: http://www.ieej.or.jp/ aperc/2006pdf/Outlook2006//ER_Malaysia.pdf (accessed on 1 November 2011).

8. Economic Planning Unit. Ninth Malaysia Plan 2006-2010; Prime Minister's Department, Economic Planning Unit: Putrajaya, Malaysia, 2006.

9. Ahmad, F. Land Use Map of Peninsular Malaysia 2006; Resource Rehabilitation and Management Division, Department of Agriculture: Putrajaya, Malaysia, 2010.

10. Yusoff, S. Renewable energy from palm oil-innovation on effective utilization of waste. J. Clean. Prod. 2006, 14, 87-93.

11. Muis, Z.; Hashim, H.; Manan, Z.; Taha, F.; Douglas, P. Optimal planning of renewable energy-integrated electricity generation schemes with $\mathrm{CO}_{2}$ reduction target. Renew. Energy 2010, $35,2562-2570$.

12. International Energy Agency. Biomass for Power Generation and CHP; International Energy Agency: Paris, France, 2007. Available online: http://www.iea.org/techno/essentials3.pdf (accessed on 10 September 2011).

13. Faaij, A. Modern biomass conversion technologies. Mitig. Adapt. Strat. Glob. Chang. 2006, 11, 335-367.

14. Sami, M.; Annamalai, K.; Wooldridge, M. Co-firing of coal and biomass fuel blends. Prog. Energy Combust. Sci. 2001, 27, 171-214.

15. Smith, K.R. Health, energy, and greenhouse-gas impacts of biomass combustion in household stoves. Energy Sustain. Dev. 1994, 1, 23-29.

16. Henson, I.E. Modeling Carbon sequestration and greenhouse gas emissions associated with oil palm cultivation and land-use change in Malaysia: A re-evaluation and a computer model. MPOB Technol. 2009, 31, 1-116.

17. Hoi, W.K. Current Status of Biomass Utilization in Malaysia. Available online: http://www. biomass-asia-workshop.jp/biomassws/01 workshop/material/Hoi\%20Why\%20Kong-word.pdf (accessed on 15 January 2011).

18. Yahaya N. Statistics of Landfills in Malaysia; National Solid Waste Management Department: Kuala Lumpur, Malaysia, 2009. 
19. Chow, M.C.; Wahid, M.B.; Chan, K.W. Availability and potential of biomass resources from the Malaysian palm oil industry for generating renewable energy. Oil Palm Bull. 2008, 56, 23-28.

20. Fact Sheets: Malaysian Palm Oil; Malaysian Palm Oil Council and Malaysian Palm Oil Board: Selangor, Malaysia, 2008.

21. Basiron, Y. Palm oil production through sustainable plantations. Eur. J. Lipid Sci. Technol. 2007, 109, 289-295.

22. Menon, N.R.; Rahman, Z.; Bakar, N. Empty fruit bunches evaluation: Mulch in plantation vs. fuel for electricity generation. Oil Palm Ind. Econ. J. 2003, 3, 15-20.

23. Abd. Jamil, A.R. Research on Biomass to Electricity: Tenaga Nasional Berhad's Experience on Coal Ash; Ministry of Natural Resources and Environment: Kuala Lumpur, Malaysia, 2011.

24. Ministry of Agriculture and Agro-based Industry Malaysia. Statsitics on Agro-Food 2009; Ministry of Agriculture and Agro-based Industry: Putrajaya, Malaysia, 2009.

25. Hussin H. Rice Mill Data; Ministry of Agriculture and Agro-Based Industry: Putrajaya, Malaysia, 2011.

26. Wong, L.C.Y.; Suraya, A.E.; Md Bashir, B.; Tey, J.Y.S. Malaysian Padi \& Rice Industry: Applications of Supply Chain Management Approach. In Proceedings of the National Rice Conference 2010, Swiss Garden Golf Resort Lumut, Perak, 28-30 June 2010.

27. Ahiduzzaman, M.; Sadrul Islam, A.K. Energy utilization and environmental aspects of rice processing industries in Bangladesh. Energies 2009, 2, 134-149.

28. National Solid Waste Management Department. Solid Waste Composition Report. Available online: http://www.kpkt.gov.my/jpspn_en/main.php?Content $=$ articles $\& A r t i c l e I D=48 \& I I D=\quad($ accessed on 14 August 2011).

29. Perlack, R.D.; Wright, L.L.; Turhollow, A.F.; Graham, R.L.; Stokes, B.J.; Erbach, D.C. Biomass as Feedstock for a Bioenergy and Bioproducts Industry: The Technical Feasibility of a Billion-Ton Annual Supply; Department of Energy: Oak Ridge, TN, USA, 2005.

30. Seabra, J.E.A.; Tao, L.; Chum, H.L.; Macedo, I.C. A techno-economic evaluation of the effects of centralized cellulosic ethanol and co-products refinery options with sugarcane mill clustering. Biomass Bioenergy 2010, 34, 1065-1078.

31. Forestry Department of Peninsular Malaysia. Forestry Statistics Peninsular Malaysia 2007; Forestry Department of Peninsular Malaysia: Kuala Lumpur, Malaysia, 2009.

32. Abdul Latip, N. List of Sawmills and Plywood Mills in Peninsular Malaysia; Ministry of Natural Resources and Environment: Putrajaya, Malaysia, 2010.

33. Yoshida, T.; Suzuki, H. Current Status of Woody Biomass Utilization in Asean Countries. Available online: http:www.intechopen.com/download/pdf/pdfs_id/11399 (accessed on 15 January 2011).

34. Basiron, Y.; Balu, N.; Chandramohan, D. Palm Oil: The driving force of world oils and fats economy. Oil Palm Ind. Econ. J. 2004, 4, 1-10.

35. Malaysian Palm Oil Board. Planted area and yield 2009. Malaysian Palm Oil Board: Kuala Lumpur, Malaysisa, 2010. Available online: http://econ.mpob.gov.my/economy/annual/stat2009/ ie_tajuk-AREA.htm (accessed on 14 August 2011).

36. Corley, R.H.V.; Tinker, P.B. The Oil Palm, 4th ed.; Blackwell Science Ltd: Oxford, UK, 2003; pp. 89-123. 
37. Zahari, M.W.; Hassan, O.A.; Wong, H.; Liang, J. Utilization of oil palm frond-based diets for beef and dairy production in Malaysia. Asian Austr. J. Anim. Sci. 2003, 16, 625-634.

38. Nori, H.; Abdul Halim, R.; Ramlan, M.F. Effects of nitrogen management fertilization practice on the yield and straw nutritional quality of commercial rice varieties. Malays. J. Math. Sci. 2008, 2, $61-71$.

39. Beer, J.; Bonnemann, A.; Chavez, W.; Fassbender, H.; Imbach, A.; Martel, I. Modelling agroforestry systems of cacao (theobroma cacao) with laurel (cordia alliodora) or poró (erythrina poeppigiana) in Costa Rica. Agrofor. Syst. 1990, 12, 229-249.

40. Lasco, R.D. Forest carbon budgets in southeast Asia following harvesting and land cover change. Sci. China Ser. C Life Sci. Engl. Ed. 2002, 45, 55-64.

41. Banzon, J.A. The coconut as a renewable energy source. Philipp. J. Coconut Stud. 1980, 5, 31-36.

42. Environmental System Resource Institute. ArcMap 9.3; ESRI: Redlands, CA, USA, 2010.

43. Lumina Decisions System Inc. Analytica Educational Optimizer, 4.4.2.2; Decisions System Inc.: Los Gatos, CA, USA, 2012.

44. Johannessen, L.M.; Boyer, G.; Mundial, B. Observations of Solid Waste Landfills in Developing Countries: Africa, Asia and Latin America; World Bank: Washington, DC, USA, 1999.

45. MeasuringWorth.com. Seven Ways to Compute the Relative Value of a U.S. Dollar Amount-1774 to Present. Available online: http:/www.measuringworth.com/uscompare/ result.php?use $\% 5 \mathrm{~B} \% 5 \mathrm{D}=\mathrm{DOLLAR} \&$ use $\% 5 \mathrm{~B} \% 5 \mathrm{D}=\mathrm{GDPDEFLATION} \&$ year_source $=1912 \&$ amount $=0.37 \&$ year_result $=2010$ (accessed 12 August 2011).

46. Ortiz, D.S.; Curtright, A.E.; Samaras, C.; Litovitz, A.; Burger, N. Near-Term Opportunities for Integrating Biomass into the U.S. Electricity Supply: Technical Considerations; The RAND Corporation: Pittsburgh, PA, USA, 2011.

47. Junginger, M.; Faaij, A.; Van den Broek, R.; Koopmans, A.; Hulscher, W. Fuel supply strategies for large-scale bio-energy projects in developing countries. Electricity generation from agricultural and forest residues in Northeastern Thailand. Biomass Bioenergy 2001, 21, 259-275.

48. Sokhansanj, S.; Fenton, J. Cost Benefit of Biomass Supply and Pre-Processing; BIOCAP Canada Foundation: Edmonton, AB, Canada, 2006.

49. Eco-Ideal Consulting, Sdn. Bhd; Mensilin Holdings, Sdn. Bhd. Barrier Analysis for the Supply Chain of Palm Oil Processing Biomass (Empty Fruit Bunch) as Renewable Fuel. Available online: http://www.eib.org.my/upload/files/Barrier\%20Analysis\%20for\%20the\%20Supply\%20 Chain\%20of\%20Palm\%20Oil\%20Processing\%20Biomass\%20(Empty\%20Fruit\%20Bunch)\%20as \%20Renewable\%20Fuel.doc (accessed on 6 December 2010).

50. Tadeo, B.D. Enhancing the Self Energy Sufficiency of Rice Mills. Available on: http://www.eaefconference.org/download/bernardo_tadeo.pdf (accessed on 13 August 2011).

51. Sebastián, F.; Royo, J.; Serra, L.; Gómez, M. Life Cycle Assessment of Greenhouse Gas Emissions from Biomass Electricity Generation: Cofiring and Biomass Monocombustion. In Proceedings of the 4th Dubrovnik Conference on Sustainable Development of Energy Water and Environment Systems, Dubrovnik, Croatia, 4-8 June 2007; pp. 4-8.

52. Malaysian Industrial Development Authority. Malaysia: Costs of Doing Business. Available online: http://www.mida.gov.my/env3/uploads/Publications_pdf/Malaysia_CODB/English/codb_ eng_Aug10.pdf (accessed 2 August 2011). 
53. LaTourrette, T.; Ortiz, D.S.; Hlavka, E.; Burger, N.; Cecchine, G. Supplying Biomass to Power Plants: A Model of the Costs of Utilizing Agricultural Biomass in Cofired Power Plants; Rand Corporation: Santa Monica, CA, USA, 2011.

54. Mahmudi, H.; Flynn, P.C. Rail vs. truck transport of biomass. Appl. Biochem. Biotechnol. 2006, 129, 88-103.

55. Lam, P.; Sokhansanj, S.; Bi, X.; Lim, C.; Naimi, L.; Hoque, M.; Mani, S.; Womac, A.; Narayan, S.; Ye, X. Bulk density of wet and dry wheat straw and switchgrass particles. Appl. Eng. Agric. 2008, 24, 351-358.

56. Segrest, S.A.; Rockwood, D.L.; Stricker, J.A.; Green, A.E.S. Biomass Co-Firing with Coal at Lakeland Utilities. Available online: http:/www.treepower.org/papers/energycrops.pdf (accessed on 20 September 2013).

57. World Bank. Commodity Prices: Hitorical Data. Available online: http://siteresources. worldbank.org/INTPROSPECTS/Resources/334934-1304428586133/PINK_DATA.xls (accessed on 11 August 2011).

58. Subbarao, P.M.V. Performance Analysis of Coal Mills. Available online: http://www.docstoc.com/ docs/52314522/PERFORMANCE-ANALYSIS-OF-COAL-MILLS (accessed on 11 August 2011).

59. Gaehr, D., Coal and Ashes Handling Machinery. In Steam; Payne, D.W., Ed; The Ferguson Publishing Company: New York, NY, USA, 1912; Volume IX, pp. 129-135.

60. Steelonthenet.com Logistics Costs for Transportation of Commodities: Transport Cost Estimates for Steel and Raw Materials. Available online: http://www.steelonthenet.com/freight.html (accessed on 11 August 2011).

61. Hughes, E.; O’Connor, D. Biomass Cofiring Update 2002: 1004319; Electric Power Research Institute: Concord, CA, USA, 2003.

62. Morrow, W.R.; Griffin, W.M.; Matthews, H.S. National-level infrastructure and economic effects of switchgrass cofiring with coal in existing power plants for carbon mitigation. Environ. Sci. Technol. 2008, 42, 3501-3507.

63. Cherubini, F.; Bargigli, S.; Ulgiati, S. Life cycle assessment (LCA) of waste management strategies: Landfilling, sorting plant and incineration. Energy 2009, 34, 2116-2123.

64. Venkatesh, A.; Jaramillo, P.; Griffin, W.M.; Matthews, H.S. Uncertainty in life cycle greenhouse gas emissions from United States coal. Energy Fuels 2012, 26, 4917-4923.

65. Ooi, T.C. Channel More to Renewable Energy Fund, Ipps and Utilities Urged. Business Times, 26 May 2012.

66. Ministry of Energy Green Technology and Water. National Renewable Energy Policy and Action Plan; Malaysian Green Technology Corporation: Putrajaya, Malaysia, 2009.

(C) 2014 by the authors; licensee MDPI, Basel, Switzerland. This article is an open access article distributed under the terms and conditions of the Creative Commons Attribution license (http://creativecommons.org/licenses/by/3.0/). 